\title{
The Challenges of the Competencies Model of Teacher Training: Examples from Chile
}

\author{
Oscar Espinoza (Corresponding author) \\ Facultad de Educación y Humanidades, Universidad de Tarapacá \\ E-mail: oespinoza@academia.cl \\ Orcid: 0000-0001-7525-2980 \\ Phone: 56983889613 \\ Luis Eduardo González
}

Programa Interdisciplinario de Investigaciones en Educación (PIIE)

Orcid: 0000-0003-1850-3899

Luis Sandoval

Universidad Tecnológica Metropolitana

Orcid: 0000-0002-8988-7888

Noel McGinn

School of Education, Harvard University

Orcid: 0000-0001-7132-2136

Bruno Corradi

Facultad de Educación y Humanidades, Universidad de Tarapacá

Orcid: 0000-0002- 4217-0900

Received: January 10, 2022 Accepted: February 10, 2022 Published: February 15, 2022

doi:10.5296/jet.v9i2.19551

URL: https://doi.org/10.5296/jet.v9i2.19551 


\section{Abstract}

This paper reports on a qualitative evaluation of the conceptual coherence of current programs of teacher training in three Chilean universities. Influenced by the Bologna Accord's emphasis on development of competencies, the national government recently called for a shift from teaching as transmission of disciplinary-based cognitive knowledge to a transdisciplinary development of cognitive and non-cognitive skills in knowledge production. The paper, based on narrative analysis, is the first assessment of how three universities have responded to the new approach. Intensive interviews with teacher training program directors asked about goals, decision criteria, and methods of assessing impact on teacher trainees. The most selective university is using formal mechanisms to validate trainees' attainment of specified competencies. In the middle and less selective universities less attention is paid to internal validation and programs rely on informal assessment mechanisms not always consistent with quality assurance requirements. The paper concludes that all three universities are guided more by labor market demands and employability of their graduates than by educational theory or research on teaching practices.

Keywords: teacher training, competencies, graduate profiles, Bologna Agreement

\section{Introduction}

During the last 30 years a variety of educational reforms have been attempted in Chile. These have included radical changes in the conception of the role of teachers and consequently in the programs that provide their training. This article presents the results of a study of major elements in the latest effort to improve the training of Basic Education (grades1-8) teachers.

Prior to 1990, most teachers in Chile were trained in post-secondary institutions called higher normal schools. Most of their professors were experienced teachers trained in those institutions. Their training programs employed different theories of teaching and learning. Shaken by low results on international tests (TIMMS, PISA, PIRLS) (Wales et al., 2014), Chile in 1974 passed a law that closed all higher normal schools and assigned the preparation of teachers to universities with faculties of education (Ministerio de Educación, 1974).

Reform of the national curriculum carried out since 1990 was accompanied by a shift of emphasis from teacher training in pedagogical science based on theories of learning which had been the major focus in normal schools (Delannoy, 2000). The new law called for more attention to acquisition and expansion of academic, disciplinary knowledge (Cox, 2016). This would require recruitment of highly qualified candidates for teacher training, and retention using incentives based on performance.

Improvements in teacher effectiveness between 1990 and 2017 failed to meet expectations. Average SIMCE scores remained essentially the same and the gap between high and low-scoring students was not reduced. Critics offered several explanations. The policies had given little attention to the "Theoretical frameworks and methods that could facilitate the development of teaching practices relevant to students..." (Fernández, 2018, p. 19). Most training programs required less than a semester of supervised practice teaching. There were no comparisons of the relative qualifications and practices of the professors who train 
teachers (Avalos, 2004; Avalos, 2018). Results of a national test of student achievement (SIMCE) were used to rank schools rather than to help teachers adjust their practices to students' interests and abilities. "Teaching to the test" reduced the scope of what was taught, resulting in encyclopedism, technification and fragmentation of learning (Gysling, 2016). Research showed that in some schools, students were exposed to only 65 per cent of curriculum content (Arango et al., 2016).

Meanwhile, the Bologna Accord (Sanders \& Dunn, 2010) and the resulting European Tuning Project (Núñez, 2016) called for development of competencies (cognitive and non-cognitive skills). The Chilean response in 2017 was a new law of education. The 1990 curriculum had segregated bodies of knowledge by their original disciplines each with a unique terminology, emphasizing cognitive knowledge (especially math and language). The new curriculum focuses on issues or problems that cut across disciplinary lines, engages students' non-cognitive skills and relates material to personal and social development (Osandón et al., 2018). Emphasis is on competencies as opposed to knowledge transfer.

Accordingly, the curriculum asks teachers to approach curriculum subjects, such as Natural Sciences Language, Mathematics, Music, Technology and other subjects, in terms of their relevance for understanding the world in which the students live. For example, the objective for Natural Sciences in the 1st grade of elementary school is to explore and describe the different types of materials in various objects according to their properties and use in daily life (Ministerio de Educación, 2018).

Teacher training in Chile currently is offered in 38 universities. Programs which end with a degree in General Basic Teaching run from 8 to 10 semesters. Basic education teachers most often teach all subjects; they are not trained as subject specialists. As universities are autonomous, the teacher training programs vary in the manner and extent to which they implement the new government policy.

Some institutions have attempted with varied success to install curricula based on teaching competencies. This has proved difficult given the high cost of implementation and difficulties in execution including the (re)training of university professors who train basic education teachers (Corvalán \& Hawes, 2006; Díaz, Poblete \& Gallardo, 2019; Moller \& Gómez, 2014). There has to date been no study of how graduate profiles were developed and the extent and depth of their coverage of the individual competencies.

\section{Literature Review}

The terms "competency" and "competence" vary in use (Brouwer \& Korthagen, 2005; Caena, 2014; Fathima et al., 2014; Pantić et al., 2011). In this paper competency is defined as possession of the skill or knowledge required to carry out a given task or mission. As the tasks of teachers are many, training programs are organized around categories of competencies.

The quality of a teacher training program can be measured in terms of the abilities and attributes that students demonstrate at the end of their university education. These attributes can be defined in the graduate profile or exit competencies that a graduate is expected to 
demonstrate (CINDA, 2004; Leyva et al., 2018). A critical question is what (kinds of) competencies should be developed?

The Bologna Accord was prompted in part by the lack of coherence in what was being taught in the universities in the European Union. Many graduates lacked competencies demanded by future employers (Allen \& Velden, 2007). Graduates of teacher training programs faced the same difficulty. A mismatch between perceived competencies and those required by prospective employers (school principals) made employment difficult (Carnevale, Cheah \& Strohl, 2012; Espinoza et al., 2019; Fenesi \& Sana, 2015). Graduates whose competencies are perceived as matching employers' demands, on the other hand, are considered to have a smoother path into the world of work (Bremner, 2017; Lindberg, 2008). The competencies' approach recommended that training plans be constructed to be coherent with the demands of the labor market (Olivos, Voisin \& Fernández, 2015), with the objective of providing future teachers with the attributes expected by employers.

The concern to match curriculum content and teacher competencies to labor market demands is not new. It was sketched out first by Bobbit (1918) and evolved into a focus on competencies and strategies laid out in DACUM (Developing a Curriculum) invented by Lawrence Coffin (Norton, 1997). DACUM workshops were promoted by universities as part of their curriculum innovation focus on learning the requirements of employers and the labor sector to define their study plans. A similar approach was developed by Dewey (1963), Kilpatrick (1918) and Tyler (1973). In the 1990s 135 European universities agreed on an action plan (called the Tuning Project) to review and restructure their processes of curriculum design, included graduates' competencies as related to the European labor market (Espinoza \& González, 2016; González \& Wagenaar, 2003).

Tuning Project proposals were replicated in the Latin American Tuning Project (Beneitone et al., 2007; Beneitone, González, \& Waagenar, 2014; Leyva et al., 2018), which has served as a guide for curriculum design in most Chilean universities (Pey, 2012) and in other countries of Latin America and the Caribbean (Ganga et al., 2018). Another impetus for adoption of the Tuning recommendations in Chile were the requirements for university accreditation adopted by the National Accreditation Commission (Espinoza, 2016; Muñoz \& Sobrero, 2006).

In Chile the important competencies were identified in two ways. The first was by choosing those that matched specific demands made by employers (school principals). The second was the construction of a learning outcomes model based on a literature review of conceptual and empirical studies of the "profiles and competencies of graduates" (Díaz-Barriga, 2006, 2011; Irigoyen, Jiménez \& Acuña, 2011). The results were combined in a study plan that listed the competencies students should have on completion of their studies (CINDA, 2008; Pucuhuaranga et al., 2019).

Critics observed that a mere definition of competencies required of teaching graduates was not sufficient (Cisternas, 2011). In addition, training programs had to systematically review their relevance and their acquisition by students. This would require mechanisms to monitor and evaluate training outcomes (Moller \& Gómez, 2014). Several approaches were developed (Leclercq, 2017; Pessoa \& Noro, 2015. Proposals also emphasized the importance of 
consulting participants and decision-makers in the labor market (Castellanos, 2011; Olivos, Voisin \& Fernández, 2015).

In Chile, the most important assessment process is now the National Diagnostic Evaluation of Preservice Teacher Training ${ }^{1}$, implemented at the end of the teacher training program as the INICIA test. Since 2016, methodologies used to assess graduate competencies, and their acquisition by students had been developed in a very limited fashion (Barrera, 2009; Medina \& González, 2020). Möller \& Gómez (2014) asked professors of Teaching Basic Education in four Chilean universities for their assessment of students' acquisition of competencies at the end of the program. Using this framework, the authors compared three subjects (Evaluation, Curriculum and Teaching Methods) in terms of what the graduate profile indicated about teachers' evaluations of students. They found that although some of the evaluations were consistent with results on the graduate profile, there were discrepancies. Espinoza, González, Sandoval and Castillo (2018) found that teacher training graduates had limited or no knowledge of their own competencies.

Given the above, it seems important to know how Faculties of Education in Chilean universities decided how to define, teach and verify the competencies of future teachers. This information can be obtained from program directors, who are solely responsible for teacher training. Their task is to interpret and put into effect policies intended to change the real curriculum. In this way, one could understand how training plans have changed in recent years and how they have changed graduates' competencies. The following research questions were based on themes appearing in the research literature reviewed.

1. How do directors of teacher training programs choose the competencies they seek to develop?

2.How do these directors validate the relevance of the chosen competencies?

3. How do program directors verify the acquisition of these competencies by their students and graduates?

\section{Methods}

This was a descriptive, qualitative study designed to explore how directors of programs in Basic Education Teaching understand the competencies that students were expected to acquire. Narrative analysis (Chase, 2005) constructed the meaning of events, episodes and objects by linking them retrospectively to the processes in which they occurred, and the meaning attached to them at that moment.

Three universities were selected to represent the full range of admission selectivity. Two criteria were used to determine the universities' selectivity: the number of years in 2016 for which the university was accredited, and the minimum PSU score required for admission. ${ }^{2}$. A

\footnotetext{
1 The National Diagnostic Evaluation of Preservice Teacher Training (INICIA) is defined in Article 27 of Law N ${ }^{\circ} 20.129$. The law specifies that success in this evaluation is a requisite for graduation from a teacher training program. Students' performance on the evaluation is used in the process of accrediting teacher training programs.

${ }^{2}$ Scores on the Uniform Selection Test (PSU) modeled after the SAT, have a sizeable correlation (0.44) with first year university grade-point average (Pearson PLC, 2013). PSU scores also are highly correlated with family socio-economic status (SES). Scores can range from 100 to 800; the standard deviation is 100.
} 
public university, identified here as the highly selective university (HSU), ranks among the top 5 Chilean universities in the QS World University list. ${ }^{3}$ Students entering the HSU must score 600 points or above on the PSU. Average scores are above 650. The second university is private and receives no direct financial subsidies from the government. A minimum of 475 points on the PSU is required for admission. Students entering this university had average scores of 550. We refer to it as the Moderately Selective university (MSU). The third university also is private and more recently established. Applicants are required to take an admission examination, but all applicants are admitted. We refer to it as the Low Selective university (LSU).

Universities in Chile can be accredited by a National Accreditation Commission that evaluates the quality of programs and staff. Accreditation can be awarded for a period of 0 to 7 years. The HSU was, in the last evaluation period, awarded 6 years. The MSU was accredited for 3 years and the LSU was not accredited. Characteristics of the three universities appear in Table 1.

Table 1. Years of Accreditation and Lowest PSU Score

\begin{tabular}{l|c|c}
\hline Selectivity Level & $\begin{array}{c}\text { Lowest PSU Score } \\
(2011-2013)\end{array}$ & Years Accredited (2016) \\
\hline Highly Selective University (HSU) & 660 & 6 \\
\hline Medium Selective University (MSU) & 476 & Not accredited \\
\hline Low Selective University (LSU) & $>400$ & \\
\hline
\end{tabular}

Source: Elaboration of authors.

Pairs of interviewers carried out in-depth interviews with three program directors in March 2018. All of them (two women and one man) have academic backgrounds in Pedagogy and postgraduate degrees in Education. Their professional experience ranged from 10 to 20 years. The interviews sought to answer the three research questions presented:

a. the underlying theory or conceptual model of the degree program for which they were responsible.

b. the validation of the relevance of the graduate competencies.

c. the verification of acquisition of graduate competencies.

Interview protocols were read by members of the research team. Constant comparison of perceptions was used for the identification of the core themes. The directors' perspectives were analyzed using Atlas Ti 8 software. Instead of quantified coding, directors' comments are cited textually to provide a nuanced insight into their perspectives and actions. In order to protect the confidentiality of the interviews, the directors' comments are identified only by the level of selectivity of their university.

\footnotetext{
${ }^{3}$ See http://www.topuniversities.com/universityrankings.
} 


\section{Results}

The findings are grouped in the sequence of the three research questions. Interviewers began by asking about the theoretical framework of the program. This morphed into a discussion of the competencies featured. The next topic was the perceived relevance of these competencies. Next the interviewers asked about the procedures used to verify the acquisition of these competencies.

\section{Definition of graduates' competencies}

In order to understand curriculum criteria that define competencies, directors were asked about the educational theory on which the curriculum is based. The program directors of the HSU and the LSU did not recall any explicit educational theory that was used to defined requisite competencies. The following statements represent their position.

(...) the philosophical perspective of the program is hard to define (..) We recognize the program has gone in several directions. It (that direction) is not (evident) in the study plan (HSU).

(...) we don't have an exclusive paradigm. It is not stated as one of our principles. (LSU).

The MSU did, however, recognize adherence to a particular educational theory, as reflected in the following statement:

I am not absolutely sure what we include in this view, but the principal focus of our project is critical theory [which the university also subscribes to] (MSU).

With respect to curricular focus, each of the three universities espoused the adoption of a competency approach similar to that proposed by the Tuning project. It is possible to identify a transversal pattern in the idea of competency formation through job performance, at least at the level of nuances. 4

In curricular terms, the focus is on competencies, however the programs are not oriented toward competencies. We operate more on the basis of learning outcomes. This is what the course outlines state (...) always in relation to graduates' competencies (HSU).

We have linked ourselves to the demand of the latest educational policies, which is to promote a competency focus (MSU).

From 2011 on we have a new study plan which incorporates the big changes of (...) generic competencies and a study plan based on learning outcomes (LSU).

Consistent with a curriculum focus based on competencies, each of the three universities emphasized that the definition of graduate competencies was conditioned by their relation to employability. This is seen in the following statement:

\footnotetext{
${ }^{4}$ It should be noted that the curriculum focus on competencies by universities was promoted by the Chilean Ministry of Education through the Higher Education Quality Improvement Program (MECESUP), financed by the World Bank.
} 
Our project is designed so that our future teachers will be well placed in the world of work, because that is what asked of teachers today (...) A teacher should be reflective, not only in the classroom, but also in the school environment, the context that surrounds him or her. That is, his/her role is to teach but in a particular context in which other variables intervene (...) We have a very good employment rate. Our graduates take only 1.8 months to find a job (HSU).

A recurrent theme in the directors' discourse was the formative brand (stamp or image) that identifies their program and university. The brand is about the distinctive capacities or competencies that the program seeks to develop in the students.

In the case of the MSU, the program director noted that there were tensions between the formative institutional brand and what an orientation toward employability implies. In this respect he stated:

We believe that if we want to be part of this system (...) we must give them [the graduates] real opportunities of employment. Therefore, we have to dialogue with the policy. But on the other hand, we know that our interest is that our students are branded. So, from this point of view, I would say that our curriculum focus is a hybrid between two tensions (MSU).

This focus on employability is especially prominent in the case of the LSU, which depends primarily on employers for evidence that their study plan is working. Regarding this statement the director stated:

...another important element that we take into consideration are the reports from employers in the accreditation processes. Indeed, they tell us that [the graduates] are very well prepared in the discipline, which supports our focus (LSU).

The identification of these formative characteristics required by the labor market was seen to work in various ways. The HSU and the MSU rely also on non-labor market sources such as inquiries with students, graduates or specific research studies.

We have done satisfaction studies with students and with graduates (...). There is a break in satisfaction [with academic training] at the point of graduation. They are more critical with respect to their training while they are in the university, but when they get into the world of work (...) they feel more satisfied when they compare their level of training with that of their peers [from other programs]. And that (...) comforts us because we are right in our focus (HSU).

Our project and focus are a result, also, of studies that have been done inside the program (...). For example, one internal study triggered that we had covered the theme of emotional education. The theme [of how] to intervene, how one goes about knowing the student and how, also, they start assuming the role (...) is the main axis of the program's curriculum (MSU).

As was indicated before, a common aspect in the programs studied is that they recognize a formative brand in the graduate competencies. In none of the three cases, however, was the 
brand derived from thinking about the program per se, rather it came more from reflection on orientations and principles at the institutional level. In the case of the HSU the allusion was to "university social responsibility" as a brand installed in students, as can be recognized in the following comment:

... our students leave the program with the discourse [motto or banner] of "university social responsibility". It is deeply rooted in our students and remains after graduation and the first years in the world of work. It is more institutional, not just of the program, but of the University (HSU).

In the MSU the distinctive features of the brand were related also to the ability to analyze and understand context and with a situational self-recognition of themselves as teachers, from a critical perspective on reality.

The brand of our program is directly related to the image [or brand] of our institution. (...) I would say that our brand (...) [is rooted in] the student's understanding of his/her role and their pedagogical practice in the school. That way, students with this brand locate themselves in a way in which they cannot understand what is happening in the school without understanding the larger context. All this is key for understanding what is happening, the school dynamics, the culture, they have to know the context. This is an identifying brand in our students (MSU).

A distinctive trait of the LSU discourse on the training process is a focus on performance or achievement, and accompanying students, which can be seen in the following testimony:

Our formative process (...) bases itself more on performance than content only. Our characteristic is accompaniment, teachers who accompany their students, including outside the classroom. We have this characteristic, teachers who are very close [to their students], one who came to school to see their difficulties, who stayed with them to give support. There is a physical accompaniment, personal, direct, always oriented toward teaching practices (LSU).

Another competency that is promoted in the training provided in the LSU is the management of diversity as visualized in the following fragment:

There are elements that differentiate us [from other universities]... Here effectively one learns to work with diversity, and that is not in the study plans [of other programs], and is a current need...The problem of attending to diversity is made clear, and is the brand of the school (LSU).

A common aspect of the discourse of the program directors of the HSU and the MSU is the emphasis they placed on the capacity of the graduate in his/her role as a teacher in the school context. They highlighted the concepts of "transformative role" or the "situationally contextualized conception" of the work of teaching as part of the formative brand contemplated in the graduate competencies

... we have tried to install a brand oriented toward the reflective-in-practice teacher, toward a teacher who is capable of gradually transforming the school spaces in 
which he/she is inserted (HSU).

We believe that the teacher is a change agent who is inserted in a concrete context in terms of relating with peers, relating with parents, with students in the complexity of the school culture. The teacher should locate himself in the school and, together with contributing to its development, pay special attention to team work (MSU).

Conceiving the teacher acting as a change agent by giving attention to employability created a tension, because the directors were aware that the present educational context does not make it easy to start up innovations and big transformations. In the case of the HSU, that issue is taken into account in practice teaching. Practice teaching experiences are designed to facilitate a new teacher's adjustment to the reality of classroom teaching.

We have graduate adjustment procedures in our teaching practices, that is, a slow form of inserting oneself in the school space. We have tried to be careful in this, to emphasize a gradual approach, because the school world is a big shock for recent graduates who find out that it is a very conservative world in which one cannot innovate quickly (HSU).

\section{Validation of the relevance of the graduate competencies}

How does the programs validate the relevance of their graduates' competencies in the context of the world of work? According to the interviewees, this is done during the training process, using practices taken from work settings and assessing student performance in those practices. The HSU introduces work practices throughout the program, validating the competencies.

We have exacerbated the discourse [of intensive practice teaching] during the cycle. It is clear then, that they [the students] are going to commit themselves in their work. They finish the practice session, and they quickly are offered a job. Right there, they can join the labor force even without graduating. This supports our graduate profile (HSU).

While the HSU relies on employers' opinions in assessing its program, it also takes into account other factors related to policies affecting the [education] sector, factors that can suggest the direction toward which the labor market is evolving. In that regard the program director stated:

To define our graduate profile [graduate competencies] we worked with employers as a source and with national and international policies. We reviewed where education was focusing. What were the demands or issues that education had at that moment? We also worked with students, about what they wanted, with professors of education and with graduates who had entered the labor force and invited all of these actors to some meetings. We laid out a matrix, even developed a graduate profile [graduate competencies] that was an answer to those demands (...) We took that profile, announced it, wrote it down, and took it to the actors to review it (HSU).

In any event, the HSU determined that a study plan could not achieve graduate competencies 
fully and absolutely aligned with the reality of the workplace. In that regard, they argued:

$\ldots$ it depends on the stance one takes with regard to the gap between what is learned and what is really required for professional work (...) It is a view (...) of how a school system, one that is quite conservative and traditional, impedes the recent graduate, the new teacher or novice, from implementing in the school what they learned in the university (...) More than a disjunction between what was learned and what is required in the school system, it is the shock of experiencing the school world, the resistance of the school world to change (HSU)

Authorities from the MSU described a process analogous to that of the HSU, in which they considered practice teaching as well as the opinions of employers and graduates as sources of information for validation of graduate competencies.

We consider different factors in order to evaluate our graduation profile [graduate competencies]. On one hand, [are] the behaviors in practice teaching which employers, directors and technical heads talk about when they observe our students, but we too are looking at [and evaluating them in terms of] other indicators. For example, in a given school we can run across three, four of our graduates working (...). Normally, what has most weight in the design of curriculum has to do with the employers' perspective. Therefore...just this last year, we put together an advisory group of employers in the development of curriculum (MSU).

With respect to the LSU, the director stated that the process of validating graduate competencies was stimulated by the INICIA test. ${ }^{5}$ In this case, in respect to validating the fit between graduate competencies and workplace demands, this might be considered to be a deficient strategy, in as much as it does not include information about the work setting.

For us the development of INICIA provided the means to evaluate our graduation profile (...). We have no systematic means to observe coherence [of the graduation profile with the demands of the workplace]. The last point [design of graduation competencies] had some steps to go before testing, and INICIA in some way is a good way for the test... as there is no standardized instrument (LSU).

\section{Verification of Acquisition of Graduate Competencies}

A complementary aspect of the curriculum design are the mechanisms used by the programs to ensure that graduates have acquired the specified competencies. This is a critical step in the formative process. In the case of the HSU there are instances in the academic formation where it is possible to assess competencies and abilities, but they are recognized as insufficient.

We have instances in which we measure the acquisition of the graduate competencies, but our weakness is that it is not a formal step, systematic, in line with the academic track. And this has multiple impacts, in curriculum and in administration, so that we are

\footnotetext{
${ }^{5}$ INICIA is a formal test of subject knowledge and pedagogical practices that teaching program graduates must past for certification as a teacher.
} 
working today on (...) changing the curriculum and designing a follow up plan that will accompany students through the program (HSU).

In the MSU mechanisms are identified ex post, in that the program looks for instances in the work process that permit identification of graduate competencies. There are, however, no systematic mechanisms to do this in the university formation process. Employability, as well as the personal experiences of graduates in their first years on the job are considered as the priority sources for evaluation and suggestions for adjustments in graduate competencies.

By evaluating the acquisition of graduate competencies, I would say that we have moved, from a more functional relationship to one where, effectively, we have to listen more to what the schools need, by means of their management teams, through their teachers. We have yet to install more solid mechanisms in order to have a proper evaluation a such, to the extent that this opinion has a major impact on our study plans (MSU).

In the LSU, there is reliance on professional practices to provide inputs about the degree of acquisition of graduate competencies, and also to understand the features that characterize the work performance of future teachers. This is an ex-post control. Under this frame the director states:

We are evaluating the acquisition of graduate competencies with the practice centers, by means of the teacher supervisors or tutors. These become aware of the weaknesses our students face in their professional practice (LSU).

\section{Discussion}

The interviews suggested that the current teacher training programs are not based on accepted theory or published research on teaching and learning nor on published research. If they are, the interviewees were not aware of their theoretical orientation. The lack of published material linking learning theory to development of competencies indicates that the program directors might have adapted existing programs from other countries or fields. This action would be consistent with the Ministry of Education's recommendations (Pey, 2012). Graduate competencies in Teaching of Basic Education in Chile were derived from a generic (European) model and modified to match national labor force requirements and the demands of the Chilean accreditation process. The current program designs lack educational theory and ignore the need to promote a more integral formation of future teachers (Muñoz \& Sobrero, 2006; Rivero et al., 2019).

A second explanation for the fact that teacher training in Chile does not link competencies training to teaching and learning theory is the accepted definition of the mission of the university in terms of employability of its graduates (Gawrycka, Kujawska, \& Tomczak, 2020). As noted earlier, the influence of the Bologna and Tuning-Europe processes was associated with a world-wide tendency to define the effectiveness of the formative process in terms of the (successful) entrance of graduates into the labor market (González \& Waagenar, 2003; Leoni, 2014). As the directors made clear in their interviews, the Chilean university accreditation process endorses this perspective. 
A third explanation is the importance attached to university image in a competitive university market (Bennett \& Ali-Choudhury, 2009). In this case, the university image or brand has defined itself as subordinate to the concerns of labor force participation, particularly obvious in the case of the LSU. Indeed, teacher training program directors in the three universities claim to have a formative image or brand derived from principles established by their parent university, and transversely applied. Employability of graduates is featured prominently in the universities' recruitment publicity.

The three programs vary in characteristics of their image. That of the HSU was defined with precision and carefully incorporated in the academic process. In the MSU and the LSU the image definitions included features that appear to have been derived more from student attributes than from those of the program's formation. The program director in the LSU defined a brand different from that announced by the university administration. This is an instance in which the formative emphases of the program appeared to be inconsistent with institutional policies.

Follow up studies of university graduates are not new in Chile (CINDA, 2012) but vary across in intensity and focus across institutions. The HSU director identified the existence of systematic mechanisms for observing student practice teaching and for obtaining performance reports from employers. The MSU and the LSU also hold "meetings with employers" and apply "rubrics for evaluating competencies at the end of the program". But these were described as informal, not a major factor in their overall strategy, and not linked with the emphasis on competencies.

In effect, the MSU and the LSU have no mechanisms to verify that the study plan has been carried out. This was one of the most self-critical features of the conversations with their program directors. These universities carried out their competency evaluations at the end of the program and the moment of entering the labor force. The HSU, on the other hand, has at several moments in the university academic formation process used a verification strategy. It is interesting that the HSU has a preventative strategy that is energized if failures of learning are observed prior to graduation. The middle and low selective universities can observe their failures only after graduates have been hired. The program directors noted this as a serious failing. These modalities are consistent with what is observed in other universities in the country (González, 2017).

The lesser reliance by these universities on formal mechanisms to verify acquisition of graduate competencies was notable. It may be that the complexity of the process of teaching and learning competencies has made it difficult to verify acquisition in resource-constrained institutions. This situation could be problematic. Failure to verify acquisition of competencies could weaken the quality of training of future teachers and lower the employability of their graduates by the labor force. At present these institutions lack the means to make corrections during the formative process. This could result in graduates with gaps in their knowledge and competency acquisition. Especially doubtful is whether the LSU can improve its training programs and its development and acquisition of competencies, so that its graduates can attend to populations with diverse capacities and needs. 


\section{Conclusions}

In recent years education has occupied center stage in public debates in Chile. Increased attention has been given to the role of the teacher, and the competencies required to raise levels of student learning. Universities have played a key role in reforming training of teachers but have taken different approaches. The three institutions included in this study differ in significant ways both in the competencies they emphasize and in methods used to ensure they are acquired.

One university (the HSU) has been directly supported financially by the State. This support has resulted in a curriculum (and graduate competencies) at least formally in accord with official requirements. The adaptation of the curriculum has been much slower in the other two institutions which receive less or no financial support. Only the influence of the accrediting organizations has resulted in those universities introducing curriculum changes. They have postponed the installation of controls and curriculum innovations to assure the quality of training plans. Most likely this is because of the high cost of these changes.

It is not advisable, based on this study, to form a general conclusion about the effectiveness of teacher training in Chile. In this way one could be more certain as to the mechanisms used in the process of curriculum innovation, and how these are animated by feedback from the work experiences of recent graduates. Finally, it should be noted that this study offers no evidence that the learning outcomes of students taught by competency-trained teachers are higher than those of students taught by teachers trained by other approaches.

\subsection{Limitations}

It is possible that existing teacher training programs are even more diverse than those included in this study. In addition, the fact that the interviewees did not know the underlying educational theories of their programs does not mean that these theories do not exist. Future research using other methods, both quantitative and qualitative, should be carried out to explore these possibilities. It may be that the content and method of some programs actually is aligned with well-established theories of teaching and learning.

\section{Funding}

This research was supported by the Agencia Nacional de Investigación y Desarrollo (ANID) through the FONDECYT Project $\mathrm{N}^{\circ} 1151016$. The authors are solely responsible for the contents of this report.

\section{Acknowledgement}

Authors acknowledge the support given by the Instituto Interuniversitario de Investigación Educativa (IESED-Chile).

\section{References}

Allen, J., \& Velden, R. (Eds.) (2007). The Flexible Professional in the Knowledge Society: General Results of the REFLEX Project. Research Centre for Education and the Labour Market. Maastricht University, The Netherlands: Springer. 
Arango, M., Evans, S., \& Quadri, Z. (2016). Education Reform in Chile: Designing a Fairer, Better Higher Education System. Graduate Policy Workshop Woodrow Wilson School of Public \& International Affairs, Princeton University. https://wws.princeton.edu/sites/default/files/content/Chile Workshop Report_HigherEd 3.15.pdf

Avalos, B. (2004). La Formación Docente Inicial en Chile. Retrieved from http://www.redfforma.cl/documentos_sitio/5006_La\%20Formacion\%20Docente\%20Inicial\% 20en\%20Chile.\%20AVALOS.pdf

Avalos, B. (2018). Teacher evaluation in Chile: highlights and complexities in 13 years of experience. Teachers and Teaching, 24(3), 297-311.

https://doi.org/10.1080/13540602.2017.1388228

Barrera, S. (2009). Evaluación del perfil de egreso en programas de pedagogía, una experiencia piloto en la Universidad Católica Silva Henríquez (UCSH). Foro Educacional, $16,85-120$.

Beneitone, P., Esquetini, C., González, J, Maletá, M., Siuffi, G., \& Wagenaar, R. (Eds) (2007). Reflexiones y Perspectivas de la Educación Superior en América Latina. Informe Final Proyecto Tuning América Latina 2004 - 2007. Bilbao, España: Universidad de Deusto.

Beneitone, P., González, J., \& Waagenar, R. (Eds.) (2014). Meta-perfiles y perfiles. Una nueva aproximación para las titulaciones en América Latina. Bilbao, España: Universidad de Deusto.

Bennett, R., \& Ali-Choudhury, R. (2009). Prospective Students' Perceptions of University Brands: An Empirical Study. Journal of Marketing for Higher Education, 19(1), 85-107. https://doi.org/10.1080/08841240902905445

Bobbit, F. (1918). The curriculum. Massachusetts, USA: The Riverside Press.

Bremner, P. (2017). From fourth year to the outside world: Are we making our fashion graduates 'work ready' - are their skills transferable into the workplace? $3^{\text {rd }}$. International Enhancement in Higher Education Conference.

http://www.enhancementthemes.ac.uk/docs/paper/8-1-3-transition-out-of-university-into-wor k.pdf?sfvrsn=4

Brouwer, N., \& Korthagen, F. (2005). Can Teacher Education Make a Difference?. American Educational Research Journal, 42(1). https://doi.org/10.3102/00028312042001153

Caena, F. (2014). Teacher competence frameworks Europe: Policy-as-discourse and policy-as-practice. European Journal of Education, 49(3), 311-331.

https://doi.org/10.1111/ejed.12088

Carnevale, A., Cheah, B., \& Strohl, J. (2012). Hard times: college majors, unemployment and earnings: not all college degrees are created equal. Washington, DC: Georgetown University Center on Education and the Workforce. 
Castellanos, O. (2011). Manual de Validación de Perfiles Profesionales y Estándares de Competencia. Cuadernos de Educación y Desarrollo, 3(27).

http://www.eumed.net/rev/ced/27/oac.htm

Chase, S. (2005). Narrative Inquiry: Multiple Lenses, Approaches, Voices. In N. Denzin \& Y. Lincoln (Eds.), The Sage handbook of qualitative research (pp. 651-679). Thousand Oaks, CA: Sage Publications Ltd.

CINDA (2004). Competencias de Egresados Universitarios. Santiago, Chile: CINDA.

CINDA (2008). Diseño Curricular basado en competencias y aseguramiento de la calidad en educación superior. Santiago, Chile: CINDA.

CINDA (2012). Seguimiento de egresados e inserción laboral. Santiago, Chile: CINDA.

Cisternas, T. (2011). La investigación sobre formación docente en Chile. Territorios explorados e inexplorados. Revista Calidad en la Educación, 35, 131-164.

https://doi.org/10.4067/S0718-45652011000200005

Corvalán, Ó., \& Hawes, G. (2006). Aplicación del enfoque de competencias en la construcción curricular de la Universidad de Talca, Chile. Revista Iberoamericana de Educación, 40(1), 1-17. https://rieoei.org/historico/deloslectores/1463Corvalan.pdf

Cox, C. (2016). Teacher education in Chile: Trends in social and policy pressures for change and evolution of its organisational and knowledge bases. In B. Moon (Ed.), Do universities have a role in the education and training of teachers? An international analysis of policy and practice (pp. 187-212). Cambridge University Press.

Delannoy, F. (2000). Education Reforms in Chile, 1980-98: A Lesson in Pragmatism. In Country Studies Education Reform and Management Publication Series (Vol. 1). http://web.worldbank.org/archive/website00238I/WEB/PDF/DELANNOY.PDF

Dewey, J. (1963). Experience and Education. New York: Collier Books.

Díaz, V., Poblete, A., \& Gallardo, M. (2019). Rediseño curricular por competencias: experiencia en la formación inicial universitaria en Chile. Revista Iberoamericana de Educación Superior, 10(27), 72-91. https://doi.org/10.22201/iisue.20072872e.2019.27.341

Díaz-Barriga, A. (2006). El enfoque de competencias en la educación ¿Una alternativa o un disfraz de cambio? Perfiles Educativos, 28(111), 7-36.

Espinoza, Ó. (2016). El Rol del Banco Mundial en la Conformación de las Políticas de Educación Superior en Sociedades en Desarrollo. In A. Fávero \& G. Tauchen (Comps), Políticas de Educacao Superior e Docecia Universitária: Diálogos Sul-Sul. (pp.15-71). Curitiba, Brasil: Editora CRV.

Espinoza, Ó., \& González, L. (2016). La Educación Superior en Chile y las Repercusiones del Acuerdo de Bolonia. Revista Internacional de Educacao Superior, 2(1), 89-117. https://doi.org/10.22348/riesup.v2i1.7530 
Espinoza, Ó., González, L., Sandoval, L., \& Castillo, D. (2018). Assessment of academic training and job placement in graduates from teaching in basic education programs in Chile. Educação em Revista, 34. https://doi.org/10.1590/0102-4698188596

Espinoza, Ó., McGinn, N., González, L., Castillo, D., \& Sandoval, L. (2019). Factors that Affect Post Graduation Satisfaction of Chilean University Students. Studies in Higher of Education, 44(6), 1023-1038. https://doi.org/10.1080/03075079.2017.1407306

Fathima, M., Sasikumar, N., \& Roja, M. (2014). Enhancing Teaching Competency of Graduate Teacher Trainees through Metacognitive Intervention Strategies. American Journal of Applied Psychology, 2(1), 27-32. https://doi.org/10.12691/ajap-2-1-5

Fenesi, B., \& Sana, F. (2015). What is Your Degree Worth? The Relationship. Between Post-Secondary Programs and Employment Outcomes. Canadian Journal of Higher Education, 45(4), 383-399. https://doi.org/10.47678/cjhe.v45i4.183604

Fernández, B. (2018). Framing Teacher Education: Conceptions of Teaching, Teacher Education, and Justice in Chilean National Policies. Education Policy Analysis Archives, 26(34). https://doi.org/10.14507/epaa.26.2806

Ganga, F., Valderrama, C., Urbina, J., Virgilli, M., \& Quiroz, J. (2018). Nuevos paradigmas en la educación superior chilena. In Ó. Leyva, F. Ganga, J. Tejada \& A. Hernández (Coord), La formación en competencias en la educación superior: Alcances y limitaciones desde referentes de México, España y Chile (pp.343-364). Ciudad de México: Tirant Humanidades.

Gawrycka, M., Kujawska, J., \& Tomczak, M. (2020). Competencies of graduates as future labour market participants - preliminary study, Economic Research. Ekonomska Istraživanja, 33(1), 1095-1107. https://doi.org/10.1080/1331677X.2019.1631200

González, J., \& Wagenaar, R. (Eds.) (2003). Tuning Educational. Structures in Europe. Informe Final. Bilbao: Universidad de Deusto.

González, L. (2017). Evaluación del logro de perfiles de egreso: experiencias universitarias. Santiago, Chile: CINDA.

Gysling, J. (2016). A 20 años de la reforma curricular: reflexiones para una revisión del currículum de educación media. Revista Docencia, 59(1), 14-25.

Irigoyen, J., Jiménez, M., \& Acuña, F. (2011). Competencias y educación superior. Revista Mexicana de Investigación Educativa, 16(48), 243-266.

Kilpatrick, W. (1918). The Project Method. New York: Teachers College Record, Columbia University.

Leclercq, D. (2017). Diez preguntas para autoevaluar el perfil de egreso, el programa y las asignaturas. Desafíos ejemplificados. In L. García-Calderón (Ed.), La evaluación de competencias en la educación superior. (pp.15-54). Lima, Perú: Pontificia Universidad Católica.

Leoni, R. (2014). Graduate employability and the development of competencies. The 
incomplete reform of the "Bologna process". International Journal of Manpower, 35(4), 448-469. https://doi.org/10.1108/IJM-05-2013-0097

Leyva, Ó., Ganga, F., Tejada, J., \& Hernández, A. (Coord.) (2018). La formación en competencias en la educación superior: Alcances y limitaciones desde referentes de México, España y Chile. Ciudad de México, México: Tirant Humanidades.

Lindberg, M. (2008). Diverse routes from school, via higher education, to employment: A comparison of nine European countries. Turku: UNIPRINT.

Medina, J., \& González, J. (2020). Aproximación cuantitativa del logro del perfil de egreso desde la perspectiva de los estudiantes. Revista Meta: Avaliação, 12(35), 364-382. https://doi.org/10.22347/2175-2753v12i35.2500

Ministerio de Educación (1974). Decreto Ley 353 Fija normas sobre el sistema de formación docente y dispone medidas relativas a las Escuelas Normales del país. http://bcn.cl/2gvjt

Ministerio de Educación (2018). Curriculum en Linea.

https://www.curriculumenlineamineduc.cl/605/w3-article-18368.html

Moller, I., \& Gómez, H. (2014). Coherencia entre perfiles de egreso e instrumentos de evaluación en carreras de educación básica en Chile. Calidad en la Educación, 41, 17-49. https://doi.org/10.4067/S0718-45652014000200002

Muñoz, A., \& Sobrero, V. (2006). Proyecto Tuning en Chile: Análisis de procesos de internacionalización de la educación superior. Calidad en la Educación, 24, 249-271. https://doi.org/10.31619/caledu.n24.278

Norton, R. (1997). DACUM Handbook. Leadership Training Series $\mathrm{N}^{\circ}$ 67. Center on Education and Training for Employment: Ohio State University.

Núñez, L. (2016). Reforma en educación superior y procesos de innovación curricular en Psicología: una revisión bibliográfica y reflexiva. Memoria para optar por el título de Licenciada en Psicología. Santiago: Facultad de Ciencias Sociales, Universidad de Chile.

Olivos, M., Voisin, S., \& Fernández, J. (2015). Evaluación del perfil de egreso de profesores de francés de parte de los empleadores: propuestas de mejora y desarrollo. Revista Electrónica Actualidades Investigativas en Educación, 15(1), 1-16.

https://doi.org/10.15517/aie.v15i1.17590

Osandón, L., Caro, M., Magendzo, A., Abraham, M., Lavin, S., González, F., \& Cabaluz, J. (2018). Estado, mercado y currículum escolar: la experiencia chilena (1964-2018). Serie Cuestiones fundamentales y actuales del currículo, el aprendizaje y la evaluación, $\mathrm{N}^{\circ} 20$. http://unesdoc.unesco.org/images/0026/002652/265296s.pdf

Pantić, N., Wubbels, T., \& Mainhard, T. (2011). Teacher competence as a basis for teacher education: Comparing views of teachers and teacher educators in Five Western Balkan countries. Comparative Education Review, 55(2), 165-188. https://doi.org/10.1086/657154

Pearson, P. L. C. (2013). Final Report Evaluation of the Chile PSU. London. Retrieved from 


\section{Macrothink}

http://portales.mineduc.cl/usuarios/mineduc/doc/201301311057540.Chile_PSU-Finalreport.p df

Pessoa, T., \& Noro, L. (2015). Pathways for graduation evaluation in Dentistry: logical model building and validation criteria. Ciência \& Saúde Coletiva, 20(7), 2277-2290. https://doi.org/10.1590/1413-81232015207.13182014

Pey, R. (2012). Innovación Curricular en las Universidades del Consejo de Rectores. Reflexiones y procesos en las Universidades del Consejo de Rectores. Valparaíso, Chile: Editorial Universidad de Valparaíso.

Pucuhuaranga, T., Hilario, N., \& Huamán, L. (2019). Modelo de evaluación del perfil de egreso en estudiantes de educación - Universidad Nacional del Centro del Perú. Revista Espacios, 40(39), 27-38.

Rivero, R., Arancibia, V., Claro, S., Lagos, F., \& Hurtado, C. (2019). Organización de la formación práctica de futuros docentes de educación primaria en Chile: Estudio exploratorio desde las universidades. Calidad en la Educación, 50, 12-48.

https://doi.org/10.31619/caledu.n50.614

Sanders, R., \& Dunn, J. (2010). The Bologna Accord: A Model of Cooperation and Coordination. Quest, 62(1), 92-105. https://doi.org/10.1080/00336297.2010.10483634

Tyler, R. (1973). Principios Básicos del Currículo. Buenos Aires, Argentina: Troquel.

Wales, J., Ali, A., Nicolai, S., Morales, F., \& Contreras, D. (2014). Improvements in the Quality of Basic Education: Chile's Experience.

https://www.odi.org/sites/odi.org.uk/files/odi-assets/publications-opinion-files/9067.pdf

\section{Copyright Disclaimer}

Copyright for this article is retained by the author(s), with first publication rights granted to the journal.

This is an open-access article distributed under the terms and conditions of the Creative Commons Attribution license (http://creativecommons.org/licenses/by/4.0/). 